\title{
Obstetrical anal sphincter injuries and outcome of primary repair
}

\author{
Gauri J. Desai, Ketaki K. Junnare*
}

Department of Obstetrics and Gynaecology, Smt. Kashibai Navle Medical College and General Hospital, Pune, Maharashtra, India

Received: 20 August 2016

Accepted: 15 September 2016

\section{*Correspondence:}

Dr. Ketaki K. Junnare,

E-mail: ketaki.junnare@yahoo.com

Copyright: () the author(s), publisher and licensee Medip Academy. This is an open-access article distributed under the terms of the Creative Commons Attribution Non-Commercial License, which permits unrestricted non-commercial use, distribution, and reproduction in any medium, provided the original work is properly cited.

\begin{abstract}
Background: OASIs (obstetrical anal sphincter injuries) involve third and fourth degree perineal tears during the process of vaginal birth. It is a grave complication as it can affect quality of life. Incidence of OASIs is on rise in developed countries. We have analyzed OASIs data from a teaching institute in India.

Methods: It was a retrospective study. Data was collected from delivery register, postnatal care OPD register and case sheets of patients with OASIs. Data was analyzed to determine incidence and risk factors. The outcome of primary suturing was assessed as per records in postnatal OPD.

Results: OASIs was detected in 35 patients (incidence $0.42 \%$ ), third degree perineal tear was seen in 31 patients, while four patients had forth degree tear. Out of these 35 patients 21 were nullipara. Sixteen patients were instrumental deliveries, 13 and 3 delivered by outlet forceps and ventouse respectively. Primary suturing of the tear was done in 34 patients under anaesthesia. Out of 24 patients who followed up in postnatal clinic at six weeks, 14 patients were asymptomatic. Two had faecal incontinence, while eight had perineal pain.

Conclusions: Nulliparity, instrumental delivery, increasing birth weight were high risk factors for obstetrical anal sphincter injuries. Obstetrician needs to be more careful while delivering a patient with multiple risk factors for OASIs. Primary suturing of anal sphincter injury with good post-operative care has a favorable outcome.
\end{abstract}

Keywords: OASIs, Parity, Instrumental deliveries, Primary suturing, Faecal incontinence

\section{INTRODUCTION}

OASIs (obstetrical anal sphincter injuries) involve third and fourth degree perineal tears during the process of vaginal birth. A third degree perineal tear is a partial or complete disruption of the anal sphincter muscles. A forth degree tear is a disruption of anal sphincter muscles with a breech in rectal mucosa. ${ }^{1}$ OASIs is a serious complication having bearing on quality of life of the patient in future. The data regarding OASIs in developed countries is elaborately reviewed. The incidence in developed countries is on rise. ${ }^{2}$ Primiparous delivery, forceps delivery, macrosomic baby, Asian race are known high risk factors for obstetrical anal sphincter injuries. ${ }^{3-5}$

Rise in incidence is reported to be due to improved recognition of tears following implementation of standardised classification of tears. ${ }^{2}$ We would like to study the incidence, etiology of OASIs in Indian population.

The objective of this study was to determine the incidence of obstetrical anal sphincter injuries (OASIs), to determine the risk factors for development of OASIs and to assess success of primary repair of OASIs. 


\section{METHODS}

This is a retrospective study. Data was collected from delivery register and postnatal OPD register. Case sheets of patients with OASIs were obtained from record section and relevant details were noted down.

\section{Inclusion criteria}

Patients delivering vaginally at Smt Kashibai Navale Medical College and General Hospital between $1^{\text {st }}$ January 2013 to $31^{\text {st }}$ December 2015.

\section{Exclusion criteria}

Patients with multiple gestations were excluded from the study as we wanted to study correlation of birth weight to OASIs. A number of variables were studied for their association with OASIs. Parity, birth weight, use of instrumental delivery and association with episiotomy was studied.

The record of primary surgical repair of all patients with OASIs was reviewed. The data was entered in a proforma and studied for competency of surgeon, use of suture material, antibiotics and laxatives in the post-operative period.

The patients follow up records at six weeks postpartum visit in postnatal OPD was reviewed. Records about faecal incontinence, pain and dyspareunia were assessed. The data was analyzed using chi square test.

\section{RESULTS}

Total number of deliveries at the SKN Medical College in the study period was 11698, of which 3310 were delivered by caesarean section. During the study period 111 patients with multiple gestation were delivered, of which, 59 were delivered vaginally. These were excluded from the study. The sample size of the study was 8329 .

OASIs was detected in 35 patients after delivery. (incidence $0.42 \%$ ) 31 women had 3rd degree perineal tear (29 patients with $3 \mathrm{~A}$, and 2 patients with 3B type of perineal tear). $4^{\text {th }}$ degree perineal tear involving mucosa of anal canal was observed in 4 patients.

Out of 35 patients with OASIs 21 were nullipara, 14 were multiparous patients. Parity is a significant factor for development of obstetrical anal sphincter injury (Table $1)$.

Table 1: Correlation of parity with OASIs.

\begin{tabular}{|lllr|}
\hline Parity & \multicolumn{2}{l}{$\begin{array}{l}\text { With anal } \\
\text { sphincter injury }\end{array}$} & $\begin{array}{l}\text { Without anal } \\
\text { sphincter injury }\end{array}$ \\
\hline Nullipara & 21 & 3198 & 3219 \\
\hline Multipara & 14 & 5096 & 5110 \\
\hline
\end{tabular}

chi square $=5.884 ; \mathrm{df}=1 ; \mathrm{p}=0.015 ;$ statistically significant
Out of 35 patients with OASIs, 13 patients were delivered by outlet forceps. 3 patients were delivered by ventouse. The incidence of OASIs in forceps delivery was $5.8 \%$ and with ventouse delivery was $1.59 \%$. All the four patients with forth degree perineal tear were instrumental deliveries, three delivered by outlet forceps and one by ventouse.

Instrumental delivery, specifically forceps was responsible for anal sphincter injury. This was statistically highly significant (Table 2).

Table 2: Correlation of mode of delivery with OASIs.

\begin{tabular}{|llll|}
\hline Mode of delivery & OASIs & $\begin{array}{l}\text { Intact anal } \\
\text { sphincter }\end{array}$ & Total \\
\hline $\begin{array}{l}\text { Non instrumental } \\
\text { vaginal delivery }\end{array}$ & 19 & 7900 & 7919 \\
\hline Forceps delivery & 13 & 209 & 222 \\
\hline Ventouse delivery & 3 & 185 & 188 \\
\hline
\end{tabular}

chi square $=159.238 ; \mathrm{df}=2 ; \mathrm{p}<0.0001 ;$ statistically highly significant.

Mediolateral episiotomy was given routinely with all instrumental deliveries.

Table 3: Role of episiotomy in nulliparous patients.

\begin{tabular}{|llll|}
\hline & OASIs & $\begin{array}{l}\text { Intact anal } \\
\text { sphincter }\end{array}$ & Total \\
\hline Nullipara with Epi & 20 & 2947 & 2967 \\
\hline Nullipara without Epi & 1 & 251 & 252 \\
\hline
\end{tabular}

chi square $=0.014 ;$ df $=1 ; \mathrm{p}=0.907 ;$ statistically not significant.

Table 4: Role of episiotomy in multiparous patients.

\begin{tabular}{|llll|}
\hline & OASIs & $\begin{array}{l}\text { Intact anal } \\
\text { sphincter }\end{array}$ & Total \\
\hline Multi with Epi & 6 & 2584 & 2590 \\
\hline Multi without Epi & 8 & 2512 & 2520 \\
\hline
\end{tabular}

chi square $=0.102 ;$ df $=1 ; \mathrm{p}=0.750 ;$ statistically not significant.

Mediolateral episiotomy was given in 5557 patients, of which 26 had OASIs. (0.32\%) Episiotomy was not used in 2772 patients of which 9 developed OASIs $(0.46 \%)$. Mediolateral episiotomy was not found to be protective against anal sphincter injury (Table 3,4 ).

Table 5: Correlation of birth weight with OASIs.

\begin{tabular}{|lllc|}
\hline Birth weight & OASIs & $\begin{array}{l}\text { Intact anal } \\
\text { sphincter }\end{array}$ & Total \\
\hline Up to $2.5 \mathrm{~kg}$ & 3 & 2439 & 2442 \\
\hline$>2.5-3 \mathrm{~kg}$ & 15 & 3923 & 3938 \\
\hline$>3-3.5 \mathrm{~kg}$ & 15 & 1689 & 1704 \\
\hline$>3.5 \mathrm{~kg}$ & 2 & 243 & 245 \\
\hline $\begin{array}{l}\text { Chi square } \\
\text { significant. }\end{array}$ & 14.844, df $=3, \mathrm{p}=0.002$, & statistically \\
\hline
\end{tabular}


Majority of patient's i. e. 31 out of 35 had baby weight 2.5 and $3.5 \mathrm{~kg}$. Two babies had weight less than $2 \mathrm{~kg}$. One baby had weight more than 3.5 to $4 \mathrm{~kg}$. Only one baby was macrosomic ( $>4 \mathrm{~kg}$ ). The incidence was high with increasing birth weight. This was found to be statistically significant (Table 5).

Table 6: Follow up of patients with OASIs.

\begin{tabular}{|ll|}
\hline & Number of patients \\
\hline Primary suturing done & 34 \\
\hline Follow up at six weeks & 24 \\
\hline Asymptomatic & 14 \\
\hline Fecal incontinence & 2 \\
\hline Perineal pain & 8 \\
\hline
\end{tabular}

Out of 35 patients with OASIs, 28 deliveries were conducted by PG residents under supervision, while 7 patients were delivered by lecturers.

Induction of labour with prostaglandins was done in seven patients and augmentation was done in 2 patients. One patient had precipitate labour.One patient had delivered unattended in a vehicle on the way to hospital.

Seven patients out 35 had no known high risk factor for developing $3^{\text {rd }}$ or $4^{\text {th }}$ degree perineal tear. Eight patients had single risk factor, while ten patients had two or three risk factors, each.

Primary suturing of the tear was done in 34 patients. The patient who had delivered in vehicle refused suturing and took discharge against medical advice. She was lost to follow up.

Suturing was done by trained gynaecologist i.e. lecturer or registrar. Suturing was done in OT under regional or general anaesthesia in 33 patients. One patient underwent suturing in Labour ward under local anaesthesia.

All patients received antibiotics for five days and were started on laxatives in postoperative period.

In 25 cases suturing was done with polyglactic acid (2.0), while 9 cases were sutured with cadgut no. 0 .

24 patients could be followed up in postnatal clinic at 6 weeks postpartum. 14 patients were asymptomatic. Two patients had developed faecal incontinence. 8 patients complained of pain at perineal site. Dyspareunia could not be assessed as none of the patients were sexually active at six weeks postpartum.

\section{DISCUSSION}

The incidence of obstetrical anal sphincter injuries was $0.42 \%$. Various studies have reported prevalence of $3^{\text {rd }}$ and $4^{\text {th }}$ degree perineal tear ranging from 0.1 and $10.29 \%$. $^{5}$
Gupta $\mathrm{N}$ has reported $0.18 \%$ incidence of $3^{\text {rd }}$ and $4^{\text {th }}$ degree perineal tear in Indian population and has attributed the low incidence to low birth weights and routine use of mediolateral episiotomies. ${ }^{6}$

I Gurol - Urganci et al has reported 5.9\% incidence of $3^{\text {rd }}$ and $4^{\text {th }}$ degree perineal tear in English population. ${ }^{2}$ This high incidence of was attributed to increased recognition of tears due to implementation of standardized classification of tears. The lower incidence in our study is probably due to lower birth weights.

Parity was found to be significant factor responsible for anal sphincter injuries. Sultan et al has attributed the increased risk for anal sphincter injuries to inelastic perineum of nulliparous women. ${ }^{4}$

Instrumental delivery was the statistically significant factor for occurance of $3^{\text {rd }}$ and $4^{\text {th }}$ degree perineal tear. All forth degree perineal tears in the study were attributed to instrumental deliveries - forceps in three patients and ventouse in one patient with forth degree perineal tear. Instrumental delivery is a documented modifiable risk factor for obstetrical anal sphincter injuries. ${ }^{2,7}$

Mediolateral episiotomy was not found to be protective of OASIs in our study. Poen et al had suggested that mediolateral episiotomy may be sphincter saving in nulliparous women. ${ }^{3}$ Handa et al had documented likelihood of decreased $3^{\text {rd }}$ degree lacerations, but increased forth degree lacerations with episiotomy. ${ }^{7}$

Birth weight was found to be statistically significant factor for development of obstetrical anal sphincter injuries. Although, only one patient with anal sphincter injury had macrosomic baby, majority of women with OASIs had birth weights between 2.5 and $3.5 \mathrm{~kg}$. Higher birth weight is a known factor responsible for anal sphincter injuries. $2,4,5$

Seven patients who developed anal sphincter injury had no known risk factor. So, a patient without any risk factor may still develop an obstetrical anal sphincter injury. Sultan AH et al has documented that it may still not be possible to predict, who will sustain a third degree tear, as third degree tears occur in less than $1 \%$ of vaginal deliveries. $^{4}$

Primary suturing was done in 34 patients under anaesthesia. All the patients received therapeutic antibiotics for five day and laxatives after primary suturing. RCOG has recommended primary suturing of all anal sphincter tears in operation theatre under anaesthesia by competent surgeon. ${ }^{1}$ All the patients should receive antibiotics and laxatives in postoperative period. Complete healing was noted in $41 \%$ of patients. Incontinence was persistent in $5 \%$ of patients, as against $3.7 \%$ noted by Mohamed R, and $41 \%$ noted by Sultan et al. $^{1,4}$ 


\section{CONCLUSION}

Nulliparity, instrumental delivery, increasing birth weight are found to be high risk factors for development of obstetrical anal sphincter injuries. Mediolateral episiotomy is not protective against OASIs. Although, it is difficult to comment as to which patients will develop OASIs, obstetrician needs to be more careful while delivering a patient with multiple risk factors for OASIs. Primary suturing of anal sphincter injury with good postoperative care has a favourable outcome.

\section{ACKNOWLEDGEMENTS}

Authors would like to thank to Head of Department of OBGY Dr. Mrs. PR Naphade for her support and encouragement.

\section{Funding: No funding sources}

Conflict of interest: None declared

Ethical approval: The study was approved by the Institutional Ethics Committee

\section{REFERENCES}

1. Mohamed R, Dixit S, Ashfaq S, Ijeneme U, Nattey J, Das M. Review of management of third and fourth degree perineal tears. Pain. 2014;3:1-6.
2. Gurol-Urganci I, Cromwell DA, Edozien LC, Mahmood TA, Adams EJ, Richmond DH, et al. Third-and fourth-degree perineal tears among primiparous women in England between 2000 and 2012: time trends and risk factors. BJOG Inter J Obste Gynaecol. 2013;120(2):1516-25.

3. Poen AC, Felt-Bersma RJF, Dekker GA, Deville W, Cuesta MA, Meuwissen SGM. Third degree obstetric perineal tears: risk factors and the preventive role of mediolateral episiotomy. BJOG Inter $\mathrm{J}$ Obste Gynaecol. 1997;104(5):563-6.

4. Sultan, Abdul H, Kamm MA, Hudson CN, Bartram CI. Third degree obstetric anal sphincter tears: risk factors and outcome of primary repair. BMJ. 1994;308(6933):887-91.

5. Hirayama F, Koyanagi A, Mori R, Zhang J, Souza JP, Gülmezoglu AM. Prevalence and risk factors for third-and fourth-degree perineal lacerations during vaginal delivery: a multi-country study. BJOG Inter J Obste Gynaecol. 2012;119(3):340-7.

6. Gupta N, Rajaram S, Mehta S. Obstetric anal sphincter injury: a clinical audit. BJOG Inter J Obste Gynaecol. 2012;119(9):1152-2.

7. Handa, Victoria L, Danielsen BH, William W, Gilbert M. Obstetric anal sphincter lacerations. Inter J Obste Gynaecol. 2001;98(2):225-30.

Cite this article as: Desai GJ, Junnare KK.

Obstetrical anal sphincter injuries and outcome of primary repair. Int J Reprod Contracept Obstet Gynecol 2016;5:3568-71. 